\title{
ВДОСКОНАЛЕННЯ МЕТОДИК АНАЛІЗУ БІОСАСЕПТОМЕТРИЧНИХ СИГНАЛІВ
}

\author{
В. М. Будник, В. Є. Васильєв, М. М. Будник \\ Інститут кібернетики ім. В. М. Глушкова НАН України
}

\begin{abstract}
Предложены количественные показатели, характеризующие сигналы магнитной восприимчивости биологических объектов. Эти показатели тестировались на экспериментальных данных от калибровочной катушки и образцах нанопорошков оксидов железа. Показано линейность экспериментальных зависимостей, что подтверждает способность созданного биосасептометра для количественных измерений наномагнитних материалов, перспективных для биомедицинских применений.
\end{abstract}

Раніше за проектом УНТЦ № 3074 (2006-2008) було виготовлено СКВІД-сасептометричну систему [1]. На сьогодні за ії допомогою проводяться вимірювання розподілу магнітних наночастинок (МНЧ) у тілі лабораторних щурів $[2,3]$. Але кількісні показники біосасептометрії не були знайдені та не обчислювались автоматично програмним забезпеченням.

Аналіз сигналів від зразків МНЧ. Прилад та експериментальна методика вимірювань детально описані в [1]. Для розуміння методики обробки на рисунку 1 наведено вигляд карти магнітного поля (КМП), звідки видно, що для карти № 2 з набору поле в максимумі $\mathrm{B}_{\mathrm{MAX}}=3972$ відліків АЦП, а в мінімумі $-\mathrm{B}_{\mathrm{MIN}}=3759$. Інформативний (корисний) сигнал сасептометра від МНЧ, поміщеними в поле намагнічування, та калібрувальний сигнал СКВІД-магнітометра описуються принципово різними виразами.

Області, в яких концентруються МНЧ в тілі малих лабораторних тварин та калібровані зразки МНЧ мають відносно малі розміри (декілька см), тому їхній розподіл поля на КМП подібний до дипольного, тобто має два сильних екстремуми поля, $\mathrm{B}_{\mathrm{MAX}}$ та $\mathrm{B}_{\text {MIN }}$ (позначені знаком «+» та «-» на рис. 1).

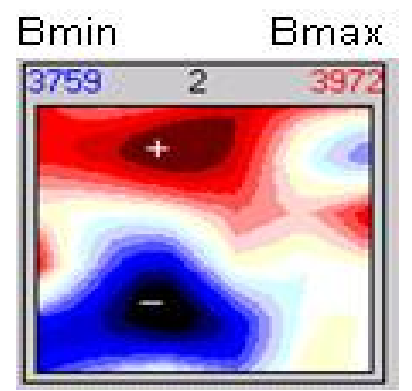

Puc. 1. КМП № 2.

Інформативним параметром є різниця поля між цими екстремумами Д (розмах КМП, 1), тому що вона, як відомо, пропорційна моменту магнітного диполя:

$\Delta=B_{M A X}-B_{M I N}$

У сасептометрі поле намагнічування змінюється за синусоїдальним законом. Отже, максимальний відгук від МНЧ буде мати місце 2 рази за період - на максимумі та мінімумі поля намагнічування. Проте значення різниць (1) можуть трохи відрізнятися в цих точках за рахунок: 1) впливу магнітних перешкод; 2) похибки струму в котушках (шуми генератора струму, дрейф опору індукційних котушок чи параметрів електроніки внаслідок нагрівання та ін.); 3 ) неточності визначення моментів екстремумів намагнічування програмою.

Тому для зменшення похибки розмах КМП усереднюють:

$\Delta_{C E P}=\frac{\Delta(+)+\Delta(-)}{2}$,

де Д (+ / -) - розмах КМП, яка відповідає максимуму / мінімуму намагнічування. Також відомо, що сигнал сасептометра пропорційний полю, а, отже, i струму намагнічування, тому його необхідно нормувати на струм:

$S_{I N F}=\frac{\Delta_{C E P}}{I_{K}}$,

де $I_{K}$ - амплітуда струму в індукційних котушках.

Аналіз сигналів при калібруванні. Калібрування виконують за допомогою міри магнітної індукції (MМI) 3-го розряду, повіреної в Харківському центрі СМС. Амплітуду розмаху каліброваного поля від ММІ у відліках АЦП оцінюють згідно (4) як різницю середніх значень на двох КМП:

$$
S_{K}=B_{C E P}(+)-B_{C E P}(-),
$$

де $B_{C E P}(+/-)$ - середній сигнал на КМП, який відповідає максимуму / мінімуму сигналу намагнічування. Останній знаходять як середнє арифметичне від значень поля в екстремумах КМП:

$$
B_{C E P}=\frac{B_{M A X}+B_{M I N}}{2} \text {. }
$$

Програмна реалізація. Для автоматизації обчислень було вдосконалено програму аналізу. На рисунку 2 наведено частину вікна програми, де відображені усереднені сигнали. У окремому вікні (справа зверху) наведені різні дані, отримані при обробці сиг-

(с В. М. Будник, В. С. Васильєв, М. М. Будник 
налів. У нижній половині цього вікна видно середній сигнал на КМП, який відповідає максимуму $B_{C E P}(+)$ $=16059$ та мінімуму намагнічування $B_{C E P}(-)=-16025$ (5), а також максимальний розмах (1) на КМП для позитивної частини Д(+)=90 та для негативної частини Д(-) = -128 усередненого сигналу. Показники (1-5) розраховуються за формулами у програмі MS Excel.

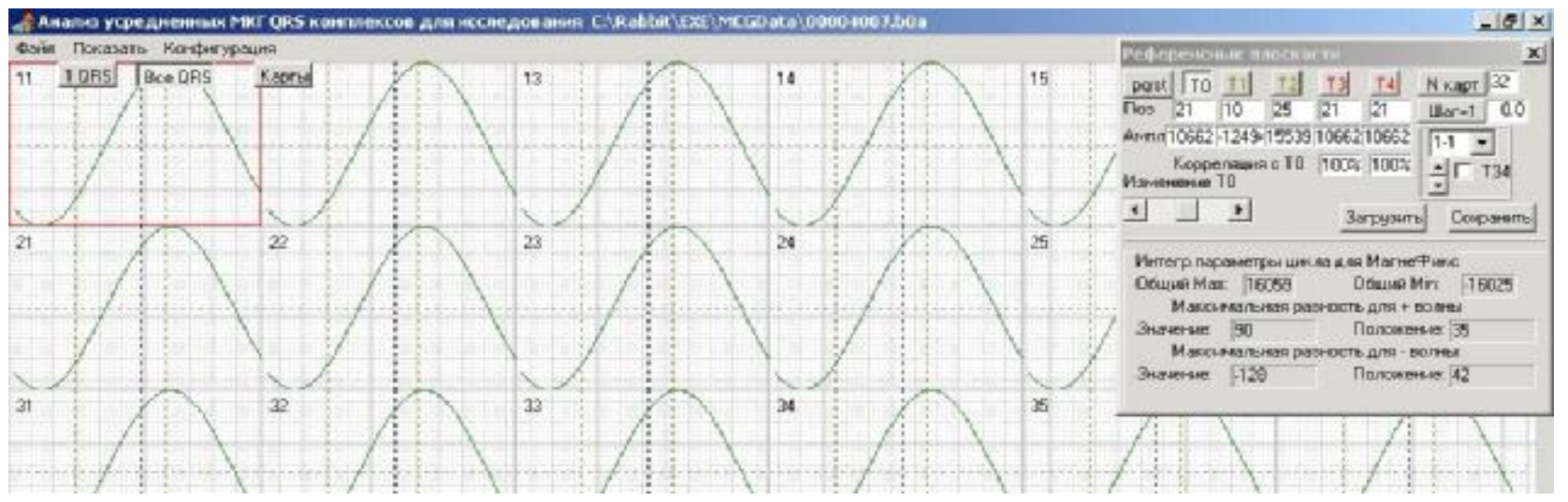

Puc. 2. Частина вікна програми аналізу усереднених сигналів.

Калібрування СКВІД-магнітометра. Спеціально виготовлену калібрувальну котушку, повірену як міру магнітної індукції (MМI) 3 коефіцієнтом передачі 4,19 пТл/мкА, одягають на хвостовик кріостата. На частоті 110 Гц у котушку з генератора послідовно подають калібрований струм прямокутної форми амплітудою 0,4, 1, 2 та 4 мкА. Нульове зна- чення вихідного сигналу СКВІД-магнітометра отримаємо при відсутності струму в калібрувальній котушці. При кожному значенні струму на основі відомого коефіцієнта передачі ММІ обчислюють магнітне поле на вході СКВІД-магнітометра. Результати калібрування показано на рисунку 3.

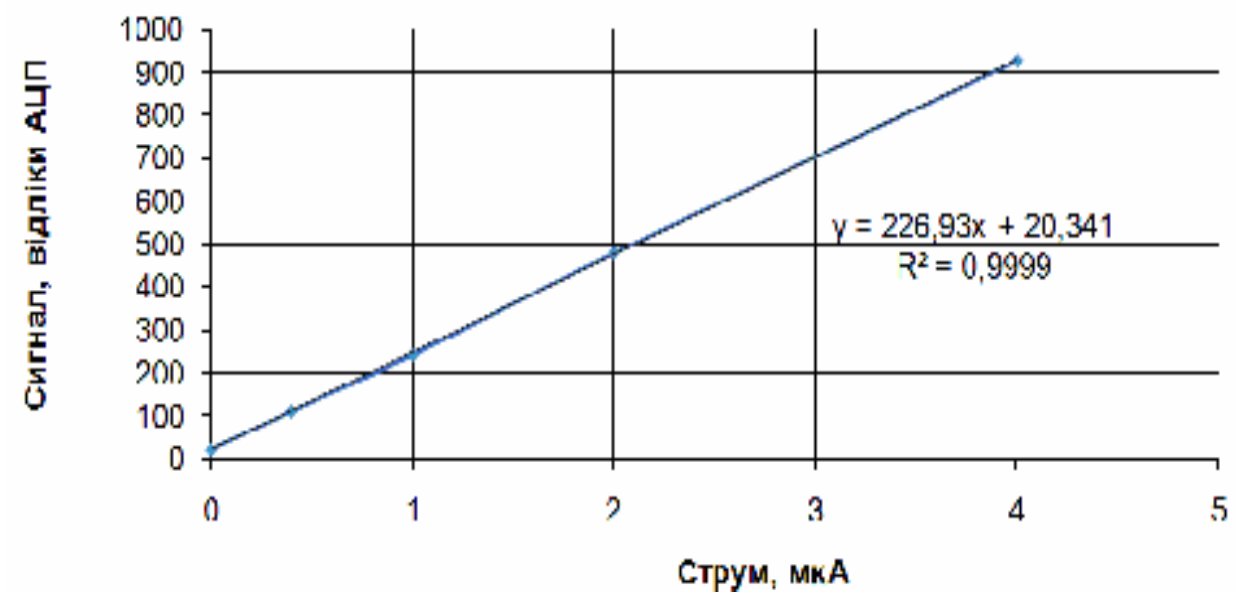

Puc. 3. Калібрувальна залежність (4) СКВІД-магнітометра.

3 рисунка 3 видно, що вихідний сигнал пропорційний струму, а отже і магнітному полю. Для отримання якісної калібрувальної залежності потрібно провести балансування вхідної антени магнітометра та не застосовувати «нормування» сигналу у П3 . Отримана калібрувальна залежність підтверджує лінійність між вхідним та вихідним сигналами $з$ дуже великою точністю, що підтверджено високою точністю лінійної регресії з коефіцієнтом $\mathrm{R}^{2}=0,9999$.

Дослідження зразків МНЧ. Під час досліджень використано МНЧ виробництва фірми Sigma Aldrich у вигляді нанопорошків $\mathrm{Fe}_{2} \mathrm{O}_{3}$ діаметром 20-25 нм та $\mathrm{Fe}_{3} \mathrm{O}_{4}$ діаметром 20-30. Для досліджень виготовлено набори каліброваних зразків, вагою 1, 2, 4, 6, 8 мг. Їх досліджено при наступних умовах: струм 1,2 A, частота намагнічування 87,1 Гц, , зразок розміщено вертикально в центрі, відстань до дна кріостата 2 мм, висота зразка 8 мм.

3 рисунка 4 видно, що для зразків масою 1 мг $€$ достовірна лінійна залежність $\left(\mathrm{R}^{2}>0,9\right)$. 


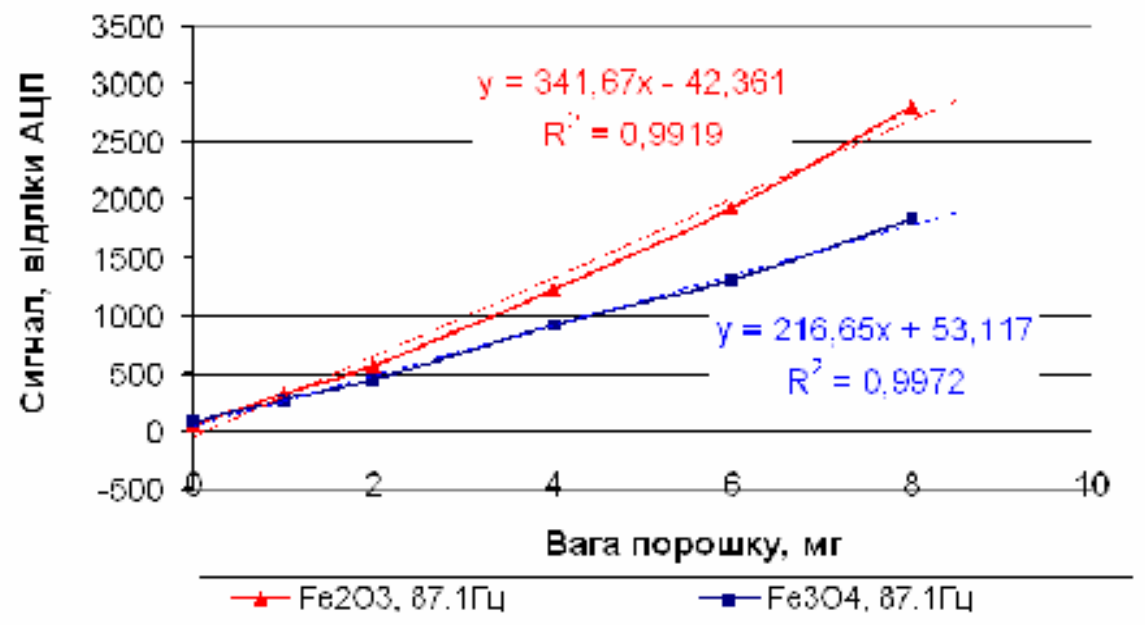

Puc. 4. Залежності інформативного сигналу (3) для зразків $\mathrm{Fe}_{2} \mathrm{O}_{3}$ i $\mathrm{Fe}_{3} \mathrm{O}_{4}$.

Висновки. Вдосконалено методику аналізу даних від зразків МНЧ та сигналів калібрування. Модернізовано ПЗ для автоматичного обчислення кількісних показників: $B_{C E P}(+), B_{C E P}(-)$, Д(+) та Д(-). Ілюстрація коректності показників та методик обробки продемонстрована на прикладі аналізу експерименталь-

\section{Література}

1. Розробка СКВІД-магнітометричної системи для дослідження МНЧ у тілі лабораторних тварин / Риженко Т., Войтович І., Мінов Ю. [та ін.] // Електроніка ізв'язок. - 2008. №3-4.-C. 164-168.

2. Виявлення здатності СКВІД-магнітометрії до візуалізації магніточутливого комплексу на основі наночасток оксиду заліза та доксорубіцину у тілі щурів-пухлиноносіїв / Будник В., Будник М., Орел В. [та ін.] // Електроніка ізв'язок. 2010. - №2.- С. 137-141.

3. Неинвазивный метод определения накопления железа в них даних, а саме калібрування магнітометра та дослідження зразків МНЧ. Показано, що калібрувальна залежність магнітометра лінійна з великою точністю $\left(\mathrm{R}^{2}=0,999\right)$. Знайдено, що для порошкових зразків масою 1 мгє достовірна лінійна залежність $\left(\mathrm{R}^{2}>0,9\right)$.

печени крыс со свинцовой интоксикацией / Лубянова И., Краснокутская Л., Дитруха Н. [и др.] // Український журнал з проблем медицини праці.-2011. - №3(27). - С. 43-46. 4. Дослідження характеристик та калібрування СКВІД-сасептометра на основі зразків магнітних наночастинок / Будник В., Сутковий П., Мінов Ю., Будник М. // Біологічна і медична інформатика та кібернетика (БМІК-2012) : матеріали щорічної науково-технічної школи-семінару, ФМШ Жукин, - К. : НАН України, Інститут кібернетики імені В. М. Глушкова. - С. 94-100. 